\title{
Immobilization of a yeast strain isolated from a petrochemical wastewater and effect of phenol on attached cells
}

\author{
Suzana Claudia Silveira Martins, Eduardo Gomes de Almeida Junior*, Larissa Maria Cidrão Guedes Fiúza, \\ Claudia Miranda Martins
}

From 5th Congress of the Brazilian Biotechnology Society (SBBIOTEC)

Florianópolis, Brazil. 10-14 November 2013

\section{Background}

Cell immobilization is a strategy to enhance the efficiency of biorremediation processes [1]. Polyurethane foams have gained relevance for their resistance to microbial attack and cost effectiveness. Although the phenotypic diversity and lower generation time of bacteria make this group the most studied, yeasts are also able to adhere and grow on inert surfaces. While free yeast cells have been studied for use in bioremediation, only in the past two decades have studies of immobilized yeast cells been reported [2]. Among the organic environmental pollutants, phenol stands out for its recalcitrance and toxicity. Therefore, the aims of this work were: (i) to evaluate the potential for immobilization of a yeast strain from a petrochemical wastewater in Brazil, (ii) to test flexible polyurethane foam as immobilizing agent for this strain and (iii) to compare the effect of phenol on immobilized and free cells.

\section{Methods}

The Candida rugosa yeast strain used in this work was isolated from oil refinery wastewater polluted by phenol. The cell surface hydrophobicity was determined by the replica method [3]. Adhesion to of xylene was evaluated according to the hidrophobicity method [4]. Qualitative production of biofilm was tested by cultivation on Congo red agar (CRA) and microbial adhesion in glass tubes (MAG) [5]. The cell suspension of C. rugosa was standardized to optical density of 0.5 at $600 \mathrm{~nm}$, corresponding to an inoculum of $10^{8}-10^{9} \mathrm{CFU} \mathrm{mL} \mathrm{m}^{-1}$. The strain was cultived on sterilized polyurethane foam

\footnotetext{
Department of Biology, Pici, BI. 909, 60455-760, Federal University of Ceara,
} Fortaleza, Brazil

\section{Results and conclusions}

The index of partition and translucent violet areas classified the strain as moderately hydrophobic. Dark red colonies on CRA plates and wall glass tubes stained red indicated that the C. rugosa strain is a biofilm producer. The growth curve of $C$. rugosa showed three phases: (1) lag phase, from 0 to $2 \mathrm{~h}$, during which the number of adhered cells was $4.3 \mathrm{Log}$ CFU cm${ }^{-2}$; (2) logarithmic phase, which lasted from 2 to $10 \mathrm{~h}$, when the cell count increased from $4.3 \mathrm{Log} \mathrm{CFU} \mathrm{cm}{ }^{-2}$ to $6.4 \mathrm{Log} \mathrm{CFU} \mathrm{cm} \mathrm{cm}^{-2}$; and (3) stationary phase, which lasted from 10 to $24 \mathrm{~h}$, when the cell concentration was $6.4 \mathrm{Log} \mathrm{CFU} \mathrm{cm}{ }^{-2}$. The concentration achieved after $24 \mathrm{~h}$, around $2.5 \times 10^{6}$

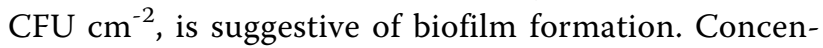
trations of $62.5 \mathrm{mg} \mathrm{L}^{-1}, 125 \mathrm{mg} \mathrm{L}^{-1}$ and $250 \mathrm{mg} \mathrm{L}^{-1}$ of phenol had a lethal effect on the cells in suspension. The increase of the number of cells at $62.5 \mathrm{mg} \mathrm{L}^{-1}$ and $125 \mathrm{mg} \mathrm{L}^{-1}$ of phenol indicated the protective effect of the cell immobilization. C. rugosa from petrochemical wastewater presented hydrophobicity and biofilm production, indicating the ability to adhere on solid surfaces. Immobilization of this strain on polyurethane foam might be a useful strategy to improve bioremediation and for treatment of phenol-polluted industrial and petrochemical wastewater. 


\section{References}

1. Ahmad SA, Shamaan NA, Arif NM, Koon GB, Shukar MY, Syed MA: Enhanced phenol degradation by immobilized Acinetobacter sp. strain AQ5NOL 1. World J Microbiol Biotechnol 2012, 28:347-352.

2. Lan W, Gang G, Jinbao W: Biodegradation of oil wastewater by free and immobilized Yarrowia lipolytica W29. J Environ Sci 2009, 21:237-242.

3. Rosenberg M: Bacterial adherence to polystyrene: a replica method of screening for bacterial hydrophobicity. Appl Environ Microbiol 1981. 42:375-377.

4. Mattos-Guaraldi AL, Formiga LCD, Andrade AFB: Cell surface hydrophobicity of sucrose fermenting and non-fermenting Corynebacterium diphtheria strains evaluated by different methods. Curr Microbiol 1999, 38:37-42.

5. Christensen GD, Simpson WA, Bisno AL, Beachey EH: Adherence of slime producing strains of Staphylococcus epidermidis to smooth surfaces. Infect Immun 1982, 37:318-326.

doi:10.1186/1753-6561-8-S4-P216

Cite this article as: Martins et al.: Immobilization of a yeast strain isolated from a petrochemical wastewater and effect of phenol on attached cells. BMC Proceedings 2014 8(Suppl 4):P216.

\section{Submit your next manuscript to BioMed Central} and take full advantage of:

- Convenient online submission

- Thorough peer review

- No space constraints or color figure charges

- Immediate publication on acceptance

- Inclusion in PubMed, CAS, Scopus and Google Scholar

- Research which is freely available for redistribution

Submit your manuscript at www.biomedcentral.com/submit 